\title{
The PRNP gene polymorphism in Rough-coated Pomeranian Landrace sheep
}

\author{
W.S. Proskura\#, R. Pilarczyk, S. Borkowska, A. Marciniak, I. Szatkowska, \\ J. Wójcik \& A. Dybus \\ Department of Ruminant Science, Faculty of Biotechnology and Animal Science, West Pomeranian University of \\ Technology in Szczecin, Dr Judyma 10, 70-460 Szczecin, Poland
}

(Received 15 January 2013; Accepted 21 May 2013; First published online 20 June 2013)

Copyright resides with the authors in terms of the Creative Commons Attribution 2.5 South African Licence.

See: http://creativecommons.org/licenses/by/2.5/za

Condition of use: The user may copy, distribute, transmit and adapt the work, but must recognise the authors and the South African Journal of Animal Science.

\begin{abstract}
Prion protein (PrP) is a membrane glycoprotein whose abnormal form is believed to cause a group of disorders known as transmissible spongiform encephalopathies (TSEs), which affect the brain and nervous system of both human beings and animals. The most familiar TSEs are Creutzfeldt-Jakob Disease (CJD) in human beings, and bovine spongiform encephalopathy (BSE) and scrapie in sheep and goats. It is well established that resistance or susceptibility to scrapie has a genetic background that is closely linked to amino acid variations within $\operatorname{PrP}$ at positions $136(\mathrm{~A} / \mathrm{V}), 154(\mathrm{R} / \mathrm{H})$ and $171(\mathrm{Q} / \mathrm{R})$. The ARR (alanine at codon 136 and arginine at codons 154 and 171) allele is associated with the highest resistance to scrapie, whereas the VRQ allele is linked to the highest susceptibility. In the present study the allelic and genotypic frequencies of the PRNP gene in the Rough-coated Pomeranian Landrace (RPL) were determined. Polymorphisms at codons 136, 154 and 171 were identified with the PCR-RFLP method. Of the eight observed genotypes, ARR/ARQ (35.9\%) and ARQ/ARQ (24.4\%) were the most frequent. This study reported a presence of AHQ/AHR genotype (2.6\%) that has not previously been recorded in any sheep breed. The predominance of wild-type ARQ (46.8\%) haplotype, which is linked to the risk of scrapie development, suggested a genetic susceptibility to scrapie in RPL sheep. Although the frequency of ARR/ARR in RPL sheep was low, the highest frequency of the ARR/ARQ genotype could be helpful in increasing the number of individuals carrying the ARR/ARR genotype and reducing the risk of genetic defects within the population.
\end{abstract}

Keywords: Sheep, scrapie, PRNP gene, polymorphism

" Corresponding author: witold.proskura@zut.edu.pl

\section{Introduction}

Prion protein (PrP) is a membrane glycoprotein expressed predominantly in the brain, but also in many other non-neural tissues, such as the lungs, heart and muscles of vertebrates (Horiuchi et al., 1995). Although PrP has been well investigated in the past, its physiological function and biological role remain unclear. Nevertheless, it is well established that prion proteins are involved in the occurrence and development of the family of prion diseases called transmissible spongiform encephalopathies (TSEs), which are characterized by neurodegeneration and protein aggregation. The most common TSEs are Creutzfeldt-Jakob disease (CJD) in human beings, and bovine spongiform encephalopathy (BSE) and scrapie in sheep and goats (Linden et al., 2008).

Transmissible spongiform encephalopathies are characterized by the aggregation of a specific protein in the nervous system, especially the brain. In sheep, aggregates are formed by scrapie prion protein $\left(\operatorname{PrP}^{\mathrm{Sc}}\right)$, an abnormal form of cellular prion protein $\left(\operatorname{PrP}^{\mathrm{C}}\right)$. Both proteins are coded by the same single-copy gene (PRNP), such that they share the same amino acid sequence and the difference between them could probably be determined by posttranslational modifications (Linden et al., 2008). 
The ovine PRNP, mapped to chromosome 13, is a highly polymorphic gene consisting of three exons, among which only the third is translated (Lee et al., 1998). Single nucleotide polymorphisms (SNPs) leading to amino acid change in PrP were observed in over 20 codons, but most of them are rare and unrelated to disease development (Goldmann et al., 2005). It was established that polymorphisms A136V (Alanine, GCC $\rightarrow$ GTC, Valine), R154H (arginine, CGT $\rightarrow$ CAT, histidine) and Q171R (glutamine, CAG $\rightarrow$ CGG, arginine) are associated with susceptibility or resistance to scrapie (Goldmann et al., 1990; Hunter et al., 1997; Baylis et al., 2004; Goldmann et al., 2005). Additionally, some studies reported another polymorphic variant coding for histidine at codon 171, but it is very rare (Acin et al., 2004; Goldmann et al., 2005). The combination of these polymorphisms results in the creation of 3-locus haplotypes and diploid genotypes, among which $\mathrm{A}_{136} \mathrm{R}_{154} \mathrm{Q}_{171}$ (hereafter $\mathrm{ARQ}$ ) haplotype and $\mathrm{AA}_{136} \mathrm{RR}_{154} \mathrm{QQ}_{171}$ (hereafter $\mathrm{ARQ} / \mathrm{ARQ}$ ) genotype are thought to be wild-type variants.

It is generally accepted that polymorphism coding for A136 and R171 confers scrapie resistance, with ARR/ARR being considered the most resistant genotype in sheep (Hunter et al., 1994). The polymorphism coding for V136 is strictly associated with susceptibility, and that coding for Q171 renders animals more vulnerable to scrapie, with VRQ/VRQ carriers being the most susceptible to the illness. Also ARQ carriers have been reported as being highly sensitive to the disease, particularly when homozygous (Goldmann et al., 1990; Hunter et al., 1997). A variation at position 154 seems to be less significant in scrapie development, but this is not consistent among studies (O’Rourke et al., 1997; Billinis et al., 2004). Baylis et al. (2004) indicated that the $\mathrm{H} 154$ allele is related to higher resistance, while Moum et al. (2005) reported this allele to be linked to greater susceptibility; but these studies were carried out on different scrapie strains. This suggests that particular types of disease agent may prefer different PRNP genotypes of the host.

Although the contribution of genetics seems to be unquestionable, scrapie is not caused by a particular genotype. It is caused by prions - the infectious agents whose nature remains partly inexplicable. Previous studies suggest that naturally occurring variants of $P R N P$, including those associated with a high risk for scrapie, cannot induce spontaneous development of the disease in sheep (Hunter et al., 1997; Bossers et al., 1999). Therefore, for scrapie to develop, the susceptible genotype and the infectious agent must both be present (Hunter \& Cairns, 1998)

Hence the European Commission (2003) introduced the requirements for the establishment of breeding programmes for resistance to TSE in sheep, among which the main point was approximation of frequency of the most resistant ARR/ARR genotype. Moreover, selective sheep breeding programmes aimed at increasing the frequency of the ARR allele have been implemented in the USA (Hunter, 2003).

This study therefore analysed the PRNP gene polymorphism at codons 136, 154 and 171 in the entire Polish population of the Rough-coated Pomeranian Landrace (RPL). This breed is a type of landrace sheep that used to be kept in small flocks along the Baltic Sea in Pomerania and Mecklenburg for its wool, meat and milk. The RPL is still considered an endangered breed and appears on the German red list of the Society for the Protection of Old and Endangered Farm Animal Breeds. There is only one flock of this breed in Poland and there are no available reports of PRNP genotypes of Rough-coated Pomeranian Landrace sheep.

\section{Materials and Methods}

The study was performed in the only flock of RPL sheep in Poland $(n=78)$, which was imported to West Pomerania in 2004. The animals are kept on an organic farm belonging to the Nature 2000 area. The DNA was isolated from $300 \mu \mathrm{L}$ of whole peripheral blood using MasterPure $^{\mathrm{TM}}$ kit (Epicentre Biotechnologies).

The polymorphisms in codons 136, 154 and 171 within the PRNP gene were analysed using the PCRRFLP method. Primers and restriction enzymes are presented in Table 1.

The PCR mixture contained $~ 80$ ng of genomic DNA, 15 pmol of each primer, 1 x PCR buffer, 1.5 $\mathrm{mM} \mathrm{MgCl} 2,0.2 \mathrm{mM}$ dNTP and 0.4 units of taq-polymerase in a total volume of $15 \mu \mathrm{L}$. The following cycles were applied: denaturation at $94{ }^{\circ} \mathrm{C} / 5 \mathrm{~min}$, followed by 33 cycles at $94{ }^{\circ} \mathrm{C} / 30 \mathrm{sec}$, primer annealing at 60 ${ }^{\circ} \mathrm{C} / 40 \mathrm{sec}$, PCR products synthesis at $72{ }^{\circ} \mathrm{C} / 40 \mathrm{sec}$ and final synthesis at $72{ }^{\circ} \mathrm{C} / 5 \mathrm{~min}$. After electrophoretical evaluation of the specificity and yield of amplification products $(4 \mu \mathrm{L}, 1.5 \%$ agarose gel, Basica Le Gqt, Prona), the remaining part $(11 \mu \mathrm{L})$ was digested with five units of an appropriate restriction enzyme at $37^{\circ} \mathrm{C}$. The restriction fragment lengths for individual genotypes are presented in Table 2. 
Table 1 Primer pairs and restriction enzymes used for determining polymorphism in codons 136, 154 and 171 of the PRNP gene

\begin{tabular}{cccc}
\hline Codon & Primer sequences & $\mathrm{T}_{\mathrm{A}}{ }^{1}$ & Restriction enzyme \\
\hline \multirow{2}{*}{$136 / 154^{2}$} & F: 5'-ATGAAGCATGTGGCAGGAG-3' & \multirow{2}{*}{$60^{\circ} \mathrm{C}$} & PagI (BspHI) \\
& R: 5'-CCAACCTGGCAAAGATTAAGA-3' & & \\
171 & F: 5'-TGTACTACAGACCAGTGGAC-3' & $60{ }^{\circ} \mathrm{C}$ & $\mathrm{MspI}$ \\
\hline
\end{tabular}

Annealing temperature.

${ }^{2}$ PCR-RFLP was designed in a way that enabled simultaneous analysis of the polymorphisms at codons 136 and 154 of the PRNP gene.

Table 2 Predicted restriction fragment lengths for individual PRNP genotypes

\begin{tabular}{cll}
\hline Codon & \multicolumn{1}{c}{ Genotype $^{1}$} & DNA restriction fragment length (bp) \\
\hline & $\mathrm{AA}_{136} \mathrm{RR}_{154}$ & \\
& $\mathrm{AV}_{136} \mathrm{RR}_{154}$ & 485 \\
& $\mathrm{VV}_{136} \mathrm{RR}_{154}$ & $485,411,74$ \\
& $\mathrm{AA}_{136} \mathrm{HH}_{154}$ & 411,74 \\
& $\mathrm{AV}_{136} \mathrm{HH}_{154}$ & 359,126 \\
& $\mathrm{VV}_{136} \mathrm{HH}_{154}$ & $359,126,74,52$ \\
& $\mathrm{AA}_{136} \mathrm{RH}_{154}$ & $359,74,52$ \\
& $\mathrm{AV}_{136} \mathrm{RH}_{154}$ & $485,359,126$ \\
& $\mathrm{VV}_{136} \mathrm{RH}_{154}$ & $485,359,74,52$ \\
& $\mathrm{QQ}_{171}$ & $411,359,74,52$ \\
& $\mathrm{QR}_{171}$ & 163 \\
& $\mathrm{RR}_{171}$ & $163,144,19$ \\
& & \\
\hline & Capital letters refer to amino acids: alanine (A), arginine (R), valine (V), histidine (H), glutamine (Q).
\end{tabular}

The DNA restriction fragments were separated in 3\% agarose gels stained with ethidium bromide. The results of electrophoretic separations were visualized under UV light and the gel photographs were archived.

\section{Results and Discussion}

A total of 78 sheep of Rough-coated Pomeranian Landrace breed was studied with regard to PRNP gene polymorphism. The genotyping of the ovine $P R N P$ gene revealed the presence of $A_{136} R_{154}$, $\mathrm{AA}_{136} \mathrm{HH}_{154}$ and $\mathrm{AA}_{136} \mathrm{RH}_{154}$ genotypes at codons 136 and 151, whereas $\mathrm{QQ}_{171}, \mathrm{QR}_{171}$ and $\mathrm{RR}_{171}$ genotypes were observed at codon 171. DNA restriction fragments for obtained variants are presented in Table 2. The combination of particular genotypes of these three loci resulted in creation of eight combined genotypes (Table 3). The following frequencies were observed: 46.8\% (ARQ), 32.1\% (ARR), 17.9\% (AHQ) and 3.2\% (AHR) (Table 4). The AHR haplotype is extremely rare and has been identified previously only in a few individuals in Germany and Slovakia. Its presence was confirmed in Nolana, Suffolk, Texel (Kutzer et al., 2002) and Valachian sheep (Tkáčiková et al., 2003) breeds, but the frequency did not exceed 1\%. Moreover, this study reported the AHQ/AHR genotype that has not been identified in any sheep heretofore.

A comparison of frequencies of common alleles and genotypes in RPL and 18 other European breeds of sheep is presented in Table 4. Of the breeds included, Kamieniecka, Olkuska, Polish Merino, Polish Mountain, Pomorska, Wrzosówka and Żelaźnieńska are indigenous Polish sheep. Allelic and genotypic 
frequencies were very diverse among compared breeds, particularly with regards to the variants that are most desirable in terms of scrapie resistance, the ARR haplotype (6.9\% - 83.8\%) and ARR/ARR genotype (0.0\% 72.0\%). In the RPL sheep flock that was analysed, 32.1\% of the sheep carried at least one ARR haplotype, but only 3.8\% were homozygous. Hence, it could be very difficult to significantly increase the number of animals with highly resistant ARR/ARR genotype. These values were relatively low, particularly when compared with Polish domestic breeds (Table 4).

Table 3 Frequencies of genotypes and haplotypes of PRNP gene in Rough-coated Pomeranian Landrace sheep $(\mathrm{n}=78)$

\begin{tabular}{cccc}
\hline Genotype & Designation $^{2}$ & Number of animals & Frequency (\%) \\
\hline $\mathrm{AA}_{136} \mathrm{RR}_{154} \mathrm{RR}_{171}$ & ARR/ARR & 3 & 3.8 \\
$\mathrm{AA}_{136} \mathrm{RR}_{154} \mathrm{QR}_{171}$ & ARR/ARQ & 28 & 35.9 \\
$\mathrm{AA}_{136} \mathrm{RR}_{154} \mathrm{QQ}_{171}$ & $\mathrm{ARQ} / \mathrm{ARQ}$ & 19 & 24.4 \\
$\mathrm{AA}_{136} \mathrm{RH}_{154} \mathrm{QQ}_{171}$ & $\mathrm{ARQ} / \mathrm{AHQ}$ & 7 & 9.0 \\
$\mathrm{AA}_{136} \mathrm{RH}_{154} \mathrm{RQ}_{171}$ & $\mathrm{ARR} / \mathrm{AHQ}$ & 13 & 16.7 \\
$\mathrm{AA}_{136} \mathrm{RH}_{154} \mathrm{RR}_{171}$ & ARR/AHR & 3 & 3.8 \\
$\mathrm{AA}_{136} \mathrm{HH}_{154} \mathrm{QQ}_{171}$ & $\mathrm{AHQ} / \mathrm{AHQ}$ & 3 & 3.8 \\
$\mathrm{AA}_{136} \mathrm{HH}_{154} \mathrm{QR}_{171}$ & AHQ/AHR & 2 & 2.6
\end{tabular}

${ }^{1}$ Capital letters refer to amino acids: alanine (A), arginine (R), histidine (H), glutamine (Q).

${ }^{2}$ Typical designation of $P R N P$ haplotypes and genotypes applied to scientific literature.

The ARQ allele is often designated the "wild type", as most of the other known haplotypes are generated by a single point mutation of the gene coding for ARQ (Tranulis, 2002). This haplotype was predominant in many of the breeds analysed in previous studies (Table 4), as well as in RPL (46.8\%) sheep. Its frequency varied from 3.8\% in Ile de France (Wiśniewska \& Mroczkowski, 2009) to 91.7\% in Grey race sheep of Kainuu (Hautaniemi et al., 2012). Despite the absence of the most undesirable VRQ haplotype in the studied population, the flock should not be considered scrapie resistant, because of the high frequency of ARQ homozygotes. Generally, the ARQ allele is associated with higher susceptibility to scrapie, especially in sheep flocks with rare or no VRQ allele (Piestrzyńska-Kajtoch \& Rejduch, 2006). Previous studies have indicated that the V136 allele is very rare or sometimes absent in breeds such as Suffolk, Lacaune and Massese, and under such circumstances, ARQ is associated with a higher susceptibility to scrapie (Hunter et al., 1997; Mutinelli et al., 2003). Moreover, higher frequencies of the ancestral ARQ allele are thought to be associated with sheep held under harsh environments (Sipos et al., 2002; Kipanyula et al., 2008).

All the breeding programmes designed for eradicating and controlling the occurrence of scrapie have aimed at indiscriminately eliminating sheep carrying the ARQ allele. Maestrale et al. (2009) proposed that the ARQ/ARQ sheep should be reassessed as a genetic category, which may potentially include animals with different scrapie susceptibility because of the presence of additional polymorphisms. The authors suggested the application of alternative strategies for breeding programmes, for instance in some rare breeds or in particular farms that show high frequency of the scrapie susceptible-associated ARQ allele.

The focus on changing the haplotype frequencies for ARR, VRQ (by positive and negative selection, respectively) in the entire sheep population is a major undertaking with long-term consequences for the TSE genetics of sheep. However, these breeding strategies are not always applicable. For instance, some rare breeds may not show high enough frequencies of the resistance-associated ARR allele. Many sheep populations show high ARQ allele frequencies, with the result that even under stringent breeding programmes this allele will still be present in these sheep populations for a long period (Goldmann et al., 2005). 
Table 4 Allelic and genotypic frequencies of PRNP gene in Rough-coated Pomeranian Landrace and various European breeds of sheep

\begin{tabular}{|c|c|c|c|c|c|c|c|c|c|c|c|c|c|c|c|c|c|c|}
\hline \multirow[b]{2}{*}{ Breed $^{1}$} & \multirow[b]{2}{*}{ Country ${ }^{2}$} & \multirow[b]{2}{*}{$\mathrm{n}$} & \multicolumn{5}{|c|}{ Haplotype frequency (\%) } & \multicolumn{10}{|c|}{ Genotype frequency (\%) } & \multirow[b]{2}{*}{ Ref. $^{4}$} \\
\hline & & & $\mathrm{ARR}^{3}$ & ARQ & AHQ & VRQ & Other & $\begin{array}{l}\text { ARR/ } \\
\text { ARR }\end{array}$ & $\begin{array}{l}\text { ARR/ } \\
\text { ARQ }\end{array}$ & $\begin{array}{l}\text { ARQ/ } \\
\text { ARQ }\end{array}$ & $\begin{array}{l}\text { ARR/ } \\
\text { AHQ }\end{array}$ & $\begin{array}{l}\text { ARQ/ } \\
\text { AHQ }\end{array}$ & $\begin{array}{l}\mathrm{AHQ} / \\
\mathrm{AHQ}\end{array}$ & $\begin{array}{l}\text { ARR/ } \\
\text { VRQ }\end{array}$ & $\begin{array}{l}\text { ARQ/ } \\
\text { VRQ } \\
\end{array}$ & $\begin{array}{l}\text { VRQ/ } \\
\text { VRQ } \\
\end{array}$ & Other & \\
\hline RPL & PL & 78 & 32.1 & 46.8 & 17.9 & - & 3.2 & 3.8 & 35.9 & 24.4 & 16.7 & 9.0 & 3.8 & - & - & - & 6.4 & 1 \\
\hline Ile de France & PL & 93 & 83.8 & 3.8 & - & 12.4 & - & 72.0 & 6.5 & - & - & - & - & 17.2 & 1.1 & 3.2 & - & 2 \\
\hline Kamieniecka & PL & 102 & 63.2 & 21.6 & - & 5.4 & 9.8 & 35.3 & 33.3 & 2.9 & - & - & - & 6.9 & 2.9 & - & 18.7 & 3 \\
\hline Olkuska & PL & 174 & 65.5 & 34.5 & - & - & - & 35.1 & 60.9 & 4.0 & - & - & - & - & - & - & - & 4 \\
\hline Polish Merino & PL & 98 & 35.2 & 63.3 & - & 1.5 & - & 7.1 & 54.1 & 35.7 & - & - & - & 2.0 & 1.0 & - & - & 5 \\
\hline Polish Mountain & PL & 31 & 40.3 & 53.2 & 6.5 & - & - & 12.9 & 51.6 & 22.6 & 3.2 & 9.7 & - & - & - & - & - & \\
\hline Pomorska & PL & 30 & 40.0 & 40.0 & 6.7 & 8.3 & 5.0 & 13.3 & 36.7 & 16.7 & 6.7 & 6.7 & & 3.3 & 3.3 & 3.3 & 10.0 & 6 \\
\hline Wrzosówka & PL & 31 & 41.9 & 38.7 & 19.4 & - & - & 6.5 & 48.4 & 9.7 & 19.3 & 12.9 & 3.2 & & & - & - & 0 \\
\hline Żelaźnieńska & PL & 31 & 46.8 & 43.6 & 4.8 & 4.8 & - & 16.1 & 54.8 & 9.7 & 3.2 & 6.5 & - & 3.2 & 6.5 & - & - & \\
\hline Chios & GR & 1013 & 6.9 & 76.1 & 8.2 & 0.4 & 8.4 & 0.4 & 11.4 & 56.0 & 0.5 & 15.0 & 0.1 & - & 0.5 & - & 16.1 & 7 \\
\hline Kainuu & FI & 48 & 8.3 & 91.7 & - & - & - & - & 16.7 & 83.3 & - & - & - & - & - & - & - & 8 \\
\hline Imroz & TR & 147 & 50.0 & 40.1 & 5.8 & 2.4 & 1.7 & 29.9 & 33.3 & 19.0 & 6.1 & 5.4 & - & - & 2.7 & 0.7 & 2.9 & 9 \\
\hline Karagouniko & GR & 100 & 28.5 & 66.0 & 3.0 & - & 2.5 & - & 57.0 & 32.0 & - & 6.0 & - & - & - & - & 5.0 & 10 \\
\hline Lacaune & RO & 159 & 15.1 & 60.4 & 5.0 & 18.9 & 0.6 & 15.1 & 33.3 & 20.1 & 5.0 & 5.7 & - & 6.3 & 12.6 & - & 1.9 & 11 \\
\hline Nolana & $\mathrm{DE}$ & 71 & 52.8 & 36.6 & - & 5.6 & 4.3 & 32.4 & 33.8 & 18.3 & - & - & - & 4.2 & 2.8 & - & 8.5 & 12 \\
\hline Rasa Aragonesa & ES & 296 & 15.0 & 70.9 & 4.8 & 2.9 & 6.4 & 2.0 & 21.0 & 51.0 & 2.0 & 6.0 & - & - & 5.0 & - & 13.0 & 13 \\
\hline Suffolk & $\mathrm{DE}$ & 87 & 27.0 & 67.2 & 1.1 & - & 4.1 & 14.9 & 20.7 & 54.0 & 1.1 & 1.1 & - & - & - & - & 8.2 & 12 \\
\hline Texel & $\mathrm{DE}$ & 231 & 28.8 & 44.4 & 1.9 & 8.2 & 15.8 & 11.7 & 19.5 & 25.1 & 0.4 & 2.2 & - & 6.5 & 7.8 & 0.4 & 26.4 & 12 \\
\hline Valachian & SK & 735 & 38.4 & 48.7 & 6.0 & 6.5 & 0.3 & 10.9 & 45.2 & 19.3 & 5.7 & 4.9 & 0.7 & 3.5 & 9.0 & 0.3 & 0.5 & 14 \\
\hline
\end{tabular}

Breeds: Kainuu, Grey race sheep of Kainuu; RPL, Rough-coated Pomeranian Landrace.

${ }^{2}$ Country: DE: Germany; ES: Spain; FI: Finland; GR: Greece; PL: Poland; RO: Romania; SK: Slovakia; TR: Turkey.

${ }^{3}$ Consecutive capital letters within haplotype refer to amino acids at codons 136, 154 and 171: alanine (A), arginine (R), histidine (H), glutamine (Q) and valine (V)

${ }^{4}$ References: (1) This study; (2) Wiśniewska \& Mroczkowski, 2009; (3) Szkudlarek-Kowalczyk et al., 2010; (4) Kaczor et al., 2011; (5) Wiśniewska et al., 2006; (6)

Lühken et al., 2008; (7) Psifidi et al., 2011; (8) Hautaniemi et al., 2012; (9) Oner et al., 2011; (10) Billins et al., 2004; (11) Otelea et al., 2011; (12) Kutzer et al., 2002;

(13) Acin et al., 2004; (14) Tkáčiková et al., 2003. 
An important factor to consider is the potential influence of these breeding programmes on major economical traits of sheep. Nevertheless, it was reported that breeding selection for scrapie-resistant sheep did not have a negative influence on milk production, reproduction (Lipsky et al., 2008; Psifidi et al., 2011) and meat traits (Vitezica et al., 2005).

\section{Conclusions}

In this study, we did not observe the VRQ genotype, but the predominance of ARQ, with frequency of 46.8\%, suggesting a genetic susceptibility to scrapie in Rough-coated Pomeranian Landrace sheep. Although the frequency of ARR/ARR was low, the highest frequency of ARR/ARQ genotype could be helpful in increasing the number of ARR/ARR individuals and reducing the risk of genetic defects within the population.

\section{References}

Acin, C., Martín-Burriel, I., Goldmann, W., Lyahyai, J., Monzón, M., Bolea, R., Smith, A., Rodellar, C., Badiola, J.J. \& Zaragoza, P., 2004. Prion protein gene polymorphisms in healthy and scrapie-affected Spanish sheep. J. Gen. Virol. 85, 2103-2110.

Baylis, M., Chihota, C., Stevenson, E., Goldmann, W., Smith, A., Sivam, K., Tongue, S. \& Gravenor, M.B., 2004. Risk of scrapie in British sheep of different prion protein genotype. J. Gen. Virol. 85, 2735-2740.

Billinis, C., Psychas, V., Leontides, L., Spyrou, V., Argyroudis, S., Vlemmas, I., Leontides, S., Sklaviadis, T. \& Papadopoulos, O., 2004. Prion protein gene polymorphisms in healthy and scrapie-affected sheep in Greece. J. Gen. Virol. 85, 547-554.

Bossers, A., Harders, F.L. \& Smits, M.A., 1999. PrP genotype frequencies of the most dominant sheep breed in a coutry free from scrapie. Arch. Virol. 144, 829-834.

European Commission, 2003. 2003/100/EC Commission decision laying down minimum requirements for the establishment of breeding programs for resistance to transmissible spongiform encephalopathies in sheep. Off. J. L 041, 41-45.

Goldmann, W., Hunter, N., Foster, J.D., Salbaum, J.M., Beyreuther, K. \& Hope, J., 1990. Two alleles of a neural protein gene linked to scrapie in sheep. Proc. Natl. Acad. Sci., USA. 87, 2476-2480.

Goldmann, W., Baylis, M., Chihota, C., Stevenson, E. \& Hunter, N., 2005. Frequencies of PrP gene haplotypes in British sheep flocks and the implications for breeding programmes. J. Appl. Microbiol. 98, 1294-1302.

Hautaniemi, M., Tapiovaara, H., Korpenfelt, S.L. \& Sihvonen, L. 2012. Genotyping and surveillance for scrapie in Finnish sheep. BMC Vet. Res. 8, 122.

Horiuchi, M., Yamazaki, N., Ikeda, T., Ishiguro, N. \& Shinagawa, M., 1995. A cellular form of prion protein (PrPC) exists in many non-neuronal tissues of sheep. J. Gen. Virol. 76, 2583-2587.

Hunter, N., 2003. Scrapie and experimental BSE in sheep. Br. Med. Bull. 66, 171-183.

Hunter, N. \& Cairns, D., 1998. Scrapie-free Merino and Poll Dorset sheep from Australia and New Zealand have normal frequencies of scrapie-susceptible PrP genotypes. J. Gen. Virol. 79, 2079-2082.

Hunter, N., Goldmann, W., Foster, J.D., Cairns, D. \& Smith, G., 1997. Natural scrapie and PrP genotype, case-control studies in British sheep. Vet. Rec. 141, 137-140.

Kaczor, U., Domoń, D., Martyniuk, E. \& Murawski, M., 2011. Polymorphism in the PRNP locus in prolific Olkuska sheep. Bull. Vet. Inst. Pulawy 55, 3-7.

Kipanyula, M.J., Chuma, I.S., Brundtland, E., Bardsen, K. \& Ulvund, M.J., 2008. Genotyping of the prion protein (PrP) gene in Red Maasai and Black Head Persian sheep in Tanzania. Small Rumin. Res. 79, 146-151.

Kutzer, T., Pfeiffer, I. \& Brenig, B., 2002. Identification of new allelic variants in the ovine prion protein (PrP) gene. J. Anim. Breed. Genet. 119, 201-208.

Lee, I.Y., Westaway, D., Smit, A.F., Wang, K., Seto, J., Chen, L., Acharya, C., Ankener, M., Baskin, D., Cooper, C., Yao, H., Prusiner, S.B. \& Hood, L.E., 1998. Complete genomic sequence and analysis of the prion protein gene region from three mammalian species. Genome Res. 8, 1022-1037.

Linden, R., Martins, V.R., Prado, M.A.M., Cammarota, M., Izquierdo, I. \& Brentani, R.R., 2008. Physiology of the prion protein. Physiol. Rev. 88, 673-728. 
Lipsky, S., Brandt, H., Lühken, G. \& Erhardt, G., 2008. Analysis of prion protein genotypes in relation to reproduction traits in local and cosmopolitan German sheep breeds. Anim. Reprod. Sci. 103, 69-77.

Lühken, G., Lipsky, S., Peter, C. \& Erhardt, G., 2008. Prion protein polymorphisms in autochthonous European sheep breeds in respect to scrapie eradication in affected flocks. Small Rumin. Res. 75, 43-47.

Maestrale, C., Carta, A., Attene, S., Galistu, A., Santucciu, C., Cancedda, M.G., Saba, M., Sechi, S., Patta, C., Bandino, E. \& Ligios, C., 2009. p.Asn176Lys and p.Met137Thr dimorphisms of the PRNP gene significantly decrease the susceptibility to classical scrapie in ARQ/ARQ sheep. Anim. Genet. 40, 982-985.

Moum, T., Olsaker, I., Hopp, P., Moldal, T., Valheim, M., Moum, T. \& Benestad, S.L., 2005. Polymorphisms at codons 141 and 154 in the ovine prion protein gene are associated with scrapie Nor98 cases. J. Gen. Virol. 86, 231-235.

Mutinelli, F., Aufiero, G.M., Pozzato, N., Marangon, S., Agrimi, U., Vaccari, G. \& Vincenzi, G., 2003. Eradication of scrapie in a Massese sheep flock by PrP allele selection. Vet. Rec. 152, 60.

Oner, Y., Yesilbag, K., Tuncel, E. \& Elmaci, C., 2011. Prion protein gene (PrP) polymorphisms in healthy sheep in Turkey. Animal 5, 1728-1733.

O’Rourke, K.I., Holyoak, G.R, Clark, W.W., Mickelson, J.R., Wang, S., Melco, R.P., Besser, T.E. \& Foote, W.C., 1997. PrP genotypes and experimental scrapie in orally inoculated Suffolk sheep in the United States. J. Gen. Virol. 78, 975-978.

Otelea, M.R., Zaulet, M., Dudu, A., Otelea, F., Baraitareanu, S. \& Danes, D., 2011. The scrapie genetic susceptibility of some sheep breeds in southeast Romanian area and genotype profiles of sheep scrapie infected. Rom. Biotech. Lett. 16, 6419-6429.

Piestrzyńska-Kajtoch, A. \& Rejduch, B., 2006. Genetic aspects of scrapie in sheep. Medycyna Wet. 62, 1344-1347. (in Polish, English abstract).

Psifidi, A., Basdagianni, Z., Dovas, C.I., Arsenos, G., Sinapis, E., Papanastassopoulou, M. \& Banos, G., 2011. Characterization of the PRNP gene locus in Chios dairy sheep and its association with milk production and reproduction traits. Anim. Genet. 42, 406-414.

Sipos, W., Kraus, M., Schmoll, F., Achmann, R. \& Baumgartner, W., 2002. PrP genotyping of Austrian sheep breeds. J. Vet. Med. A. 49, 415-418.

Szkudlarek-Kowalczyk, M., Wiśniewska, E., Milewski, S. \& Mroczkowski, S., 2010. Prion protein gene (PRNP) polymorphism in a flock of sheep of Kamieniecka breed. Bull. Vet. Inst. Pulawy 54, 645-649.

Tkáčiková, L., Hanušovská, E., Novák, M., Arvayová, M. \& Mikula, I., 2003. The PrP genotype of sheep of the improved Valachian breed. Folia Microbiol. 48, 269-276.

Tranulis, M.A., 2002. Influence of the prion protein gene, Prnp, on scrapie susceptibility in sheep. APMIS $110,33-43$.

Vitezica, Z.G., Moreno, C.R., Bouix, J., Barillet, F., Perret, G. \& Elsen, J.M., 2005. A study on associations between PrP genotypes and meat traits in French sheep breeds. Anim. Sci. 81, 325-330.

Wiśniewska, E., Lühken, G., Mroczkowski, S. \& Erhardt, G., 2006. Prion protein (PrP) gene polymorphisms and breeding for resistance to scrapie in Polish Merino sheep. Arch. Tierz. 49, 365-371.

Wiśniewska, E. \& Mroczkowski, S., 2009. Different breeding strategies for scrapie resistance depending on breed-specific PrP allele and genotype frequencies in the Polish sheep. Züchtungskunde 81, 180-189. 